\title{
Empirical analysis of three wind simulation tools to support urban planning in early stages of design
}

Análise empírica de três ferramentas de simulação vento para colaborar com o planejamento urbano em estágios iniciais de projeto

- Joana Pack Melo Sousa

UFPE, Brasil

joanapacksousa@gmail.com

Rafael Andres Castro Moya

RMIT University, Australia

s3296513@student.rmit.edu.au
- Daniel Prohasky

RMIT University, Australia

daniel.prohasky@rmit.edu.au

Carlos Eduardo Verzola Vaz

UFPE, Brasil

cevv00@gmail.com

\begin{abstract}
Este artigo apresenta a experiencia de utilização de três ferramentas de simulação de vento: Flow Design, ODS-Studio e um mini túnel de vento. O objetivo foi avaliar as vantagens e desvantagens de incorpora-las nas fases iniciais de projeto. Como tal, foram simulados três cenários urbanos e os resultados obtidos foram posteriormente comparados com as simulações efetuadas por Sousa (2014) com o programa CFD Phoenics. Como resultado o Flow Design é o mais intuitivo, mas menos preciso nos resultados. O ODS-studio é mais complexo para manipular e o mini túnel de vento o mais apropriado para analise de pontos especificos.
\end{abstract}

Keywords: Conforto Ambiental, Ventilação, CFD, Planejamento Urbano

\section{Introduction}

In the last few years it has been well documented that urbanization modifies the natural wind circulation generating areas of turbulent airflow (Gandemer, 1978; Oke,1987). For Boris (2005) is important to analyse urban aerodynamics phenomenon to determine environmental air quality, wind pressure on buildings, urban heat islands, pedestrian comfort, and ambient noise level in the surrounding. Bittencourt and Cândido (2010) complement this statement reminding that understanding the wind dispersion through the city is essential to reduce the consumption of energy in indoor spaces with artificial mechanisms of comfort like the air conditioning.

Despite natural ventilation be an important environmental parameter to be considered for the sustainability of the city it is still neglected by most architects and urban planners in Brazil. According to Melo and Barbirato (2011). the development of Brazilian cities is determined by its land use policy that defines different urban parameters, such as, land use rates, natural soil percentage, distance between constructions and building height. Some of this rules arose to ensure human comfort and healthier urban spaces with natural ventilation and light. However, the deficiency of studies involving urban prescriptions with the climatic data turns urban planning, paradoxically, responsible for the detriment of the welfare of the population. Assis (2006), reported that there was an increase in the number of studies that relate wind flow and urban development in Brazil, but in general the investigations are limited to a specific case study and there is lack of integration between the academic knowledge and the professionals that regulate and design the future of the city.

Several tools can be applied to simulate wind phenomenon in digital or physical models, providing visual and numeric information that can be used by urban planners and architects' to support their decisions. Some of these tools are based on computational fluid dynamics (CFD) system and can elaborate very sophisticated calculations, such as, ANSYS CFX, Fluent, Phoenics and Flow 3D. (Cfd online, n.d.). These computer applications are frequently used by engineers to analyze a variety of fluids like water, gas, wind, smoke. Other simulation tools such as wind tunnels can also be considered a reliable technology for airflow analysis; however it is not very common to find laboratories with this type of equipment because is extremely expensive fully incorporated into the design process because the equipment is extremely expensive (Williams et al., 2015).

These technologies are very advanced, but they demand some degree of knowledge to manipulate and to be able to interpret the results. In addition, a high initial investment is necessary, challenging their use in early stages of design process by architects (Kirkegaard, Hougaard, Staerdahl, 2008). This aspect along with a very time consuming 
simulation has been pointed out as the main reasons for the lack of integration of wind analysis in architectural design exploration (Salim and Moya, 2012; Moya, 2015). As a result, usually, when wind simulations are applied it is hired a team of experts to analyse the final design project missing the opportunity to develop more sophisticated strategies in the concept design stage (Kirkegaard et al., 2008).

Considering these difficulties of workflow, some CFD simulation tools have been developed to be used by architects for rapid visualization of airflow, interoperability with other architectural design applications and easier set up of wind parameters, looking to promote the use of these tools in the initial stages of design (Williams et al., 2015). Naboni (2013) realized in his study that some of the world's leading architecture firms have been incorporated progressively this environmental simulation tools, into their design process, analyzing energy consumption, radiation, natural light effect and airflow movement. "These simulation tools do not only have a significant impact on the way buildings are designed, but they are also changing the internal structures of architectural offices" (Naboni, 2013).

With this in mind, some investigations have been done to develop methodologies and tools to improve the integration of CFD and wind tunnel in architectural practice. For instance, Prohasky, Moya, Watkins, Burry and Burry (2014), used wind-sensing platform inside a wind tunnel to evaluate the airflow around one building concept. Similarly, Salim and Moya (2012) analyzed wind in outdoor spaces to evaluate the performance of two digital simulation software's (CFD Vasari and CFD ANYS CFX) and two physical simulation devices ( a wind tunnel and a mini wind tunnel). The study of Williams et al. (2015) tested different designs solutions of porous screen for building façade using CFD Vasari and the Mini airflow tunnel. The investigation of Moya (2015) compared the use of Vasari, ODS-Studio and ANSYS CFX for the analysis of a windbreak shelter. These studies were all focused on the building design scale.

The purpose of the current paper is to evaluate the use of two CFD programs and a mini airflow tunnel, for a brother scale of analysis, visualizing airflow in urban scenarios to support urban planner decision. The study was designed to evaluate the following aspects:

1. The tools currently developed for wind simulation in early design stages can generate a similar airflow of a sophisticated tool like CFD Phoenics at the pedestrian level?

2. What are the advantages and disadvantages in the use of these simulations tools to analyze urban scenarios?

3. How is the workflow experience during the simulation?

\section{Methodology}

The research was developed in three different phases. In the first phase was selected three wind analysis tools that were specifically developed to be used during the design process and for educational purposes. The tools chosen were two computer fluid dynamic (CFD) programs (Autodesk Flow Design, and ODS-Studio) and one mini airflow tunnel developed by Moya and Prohasky (n.d.).

In the second step, it was designated a case of study to be used as mean of comparison between all simulation tools. The area selected was simulated before by Sousa (2014) with a sophisticated and reliable CFD software (Phoenics), largely used by engineers and architects for professional and academic research. The aim was to use the results obtained in the previous investigation as analytic standard (see figure 1).

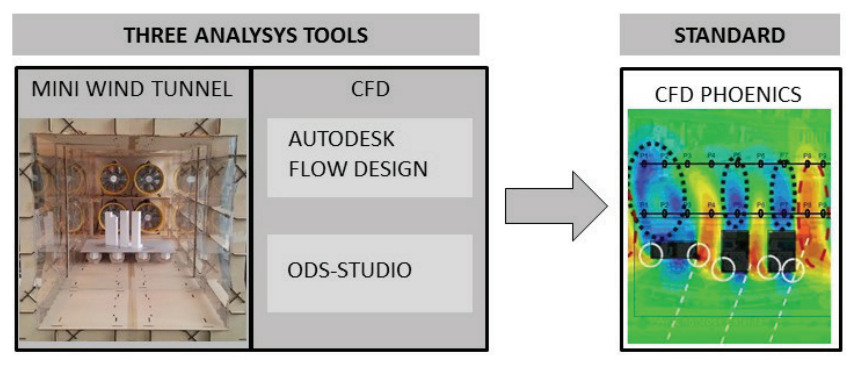

Figure 1: Methodology applied in the research. Author.

The last step was to analyse the performance and the feedback of each wind simulation tool considering time and complexity of manipulation, identifying the advantages and disadvantages of their use. Moreover, the wind velocity results generated by the simulation were compared among all tools seeking for similar pattern of airflow. For this purpose, it was established sixteen points of comparison between all images obtained at two meters above surface, representing the pedestrian level of comfort. Considering that two of the tools studied show the simulation results in dynamic images of air movement (Flow Design and mini airflow tunnel) it was necessary to record one minute video to be then translated in an excel file and transformed into a value of wind speed average. All the information was transformed into a graphic chart for further evaluation.

\section{Digital Simulation tools for airflow}

Visualization of airflow inside and around buildings usually is accomplished through digital simulation using CFD software's or with scaled models inside a wind tunnel. In Brazil this two techniques have been widely applied in academic research. For instance, the work developed by Brandão (2009) and Leite (2010) used CFD Ansys CFX, Marques (2003) and Costa (2001), made use of CFD Phoenics, while Prata (2005) and Peregrino (2005) used a wind tunnel. All of them analysed the development of the city based on urban parameters established by a masterplan and a land use policy.

Sousa (2014), during her master research also used the software Phoenics (Parabolic Hyperbolicor Elliptic Numerical Integration Code Series), created by CHAM (Concentration Heat and Momentum), a company founded in 1974. This 
software is used by engineers (civil, naval, nuclear, and chemical) architects, and designers because it allows the investigation of various processes involving fluid flow, heat and mass transfer, chemical reactions and / or combustion equipment (Cham, n.d.).

Phoenics runs three sequential modules: the pre-processor, the processor and post-processor. The preprocessor is composed of VR-Editor and Satellite, which are virtual reality editors. The processor contains a system of subroutines, called EARTH, which generates the simulation model through complex numerical calculations (Costa, 2001).Finally, the visualization of the results is in the post-processor, which is composed of the VR Viewer, PHOTON and AUTOPLOT. Sousa (2014) used the VR Viewer, which allows observing the results in the form of vectors of velocity fields or isolines.

This CFD tool has more than thirty years of development. The simulation used as analytic standard in the research was runned in the 3.6.1 version, from 2005, available in the laboratory of the Federal University of Alagoas (UFAL). It provides a very reliable demonstration of aerodynamic flow around buildings; however, this is an expensive software, difficult to be found in Universities or architectural firms. In addition, the version used did not have interoperability with other software. As a result, every step of the simulation had to be implemented in Phoenics, including creating the geometric model of the scenario. Therefore, it was very time consuming and difficult to integrate into usual architect workflows. Based on this reason, this research proposes to analyse other CFD tools available for free in the internet, trying to make a correlation between precision and usability. The following paragraphs describes each tool main characteristics:

Flow Design is a virtual wind tunnel developed by Autodesk for rapid visualization of airflow around buildings and other objects. This tool was design to be easy and intuitive to use. The interoperability with other architectural softwares like, Autocad and Revit gives the chance to easily test different design concepts. Moreover, the visualization system was projected for an interactive 2D and 3D simulation of airflow movement (Autodesk, n.d.);

ODS-studio is a platform developed to bring together many existing open-source tools. The aim was to provide rapid design and advanced technical analysis of building concepts in the early stages of design. The platform connects a modeling software called Blender (were users can create the 3D models or import from other architectural softwares, and also they can manipulate the digital mesh), with three environmental simulation programs: OpenFOAM (for CFD analysis of airflow), Radiance (for evaluation of daylight routine) and Energyplus (for calculation of energy consumption). To visualize Open FOAM simulation is also necessary the program Paraview. Furthermore, ODSstudio was developed to work in Linux, Mac and Windows operational systems. (ODS-Engineering, n.d.).

Simulation tools of airflow - the mini airflow tunnel

Since the beginning of 1890, architects have been using the wind tunnel for analysis wind flow inside and around buildings (Aynsley, 1977). Some of the techniques used for visualization of air movement are fog/smoke emission, floating particles or gas bubbles. Williams et al., (2015). Claims that "these techniques provide a qualitative approach to visualizing the pattern of wind vortices, separation flows, turbulence and changes of wind direction. Quantitative techniques typically involve the analysis of results after the experiment has taken place. Nevertheless, because of the expensive facilities required, this technology has not been fully incorporated into the design process or the education of architecture students"

Bearing in mind this limitation, two researchers from SIAL (Spatial Information Architecture Laboratory) in RMIT University developed a portable and affordable version of a regular wind tunnel they call it the mini airflow tunnel project (Moya, Prohasky, n.d.). Is a modular wind tunnel made of MDF and acrylic panels that can be cut and assembled by anyone. The template is available for free download on the web site of the project, expanding the opportunities for its use. The test chamber can have three to nine modules depending on the user need and space. Each model has $0.9 \mathrm{~m}$ wide, $0.9 \mathrm{~m}$ high and $0.6 \mathrm{~m}$ long, that can be taken apart and transported to other laboratories, when is no longer needed (see figure 2) (Moya, Prohasky, n.d.).

Four fans are installed in the inlet zone to produce a continuous airflow of approximately $4 \mathrm{~m} / \mathrm{s}$. In general, the wind tunnel is not designed to reproduce full scale wind flow conditions such as atmospheric boundary layer or turbulence intensity profiles. However, it presents a controlled and stable wind flow environment for reasonable observations of the dynamics in environmental parameters that, in situ, exist in a similar manner (Williams et al., 2015).

This mini airflow tunnel was developed along with a microelectronic wind-sensing platform for immediate feedback of the simulation. Williams et al., (2015).explains that this method combines physical simulations with digital visualization where micro anemometer sensors are placed inside the test chamber to collect wind speed data in meters per second (m/s) temperature and humidity. This information is transmitted to an arduino board that transforms this data into an interactive visualization of airflow using a digital interface of Grasshopper script inside Rhinoceros software and with the Firefly plugin (Moya, Prohasky, n.d.). 


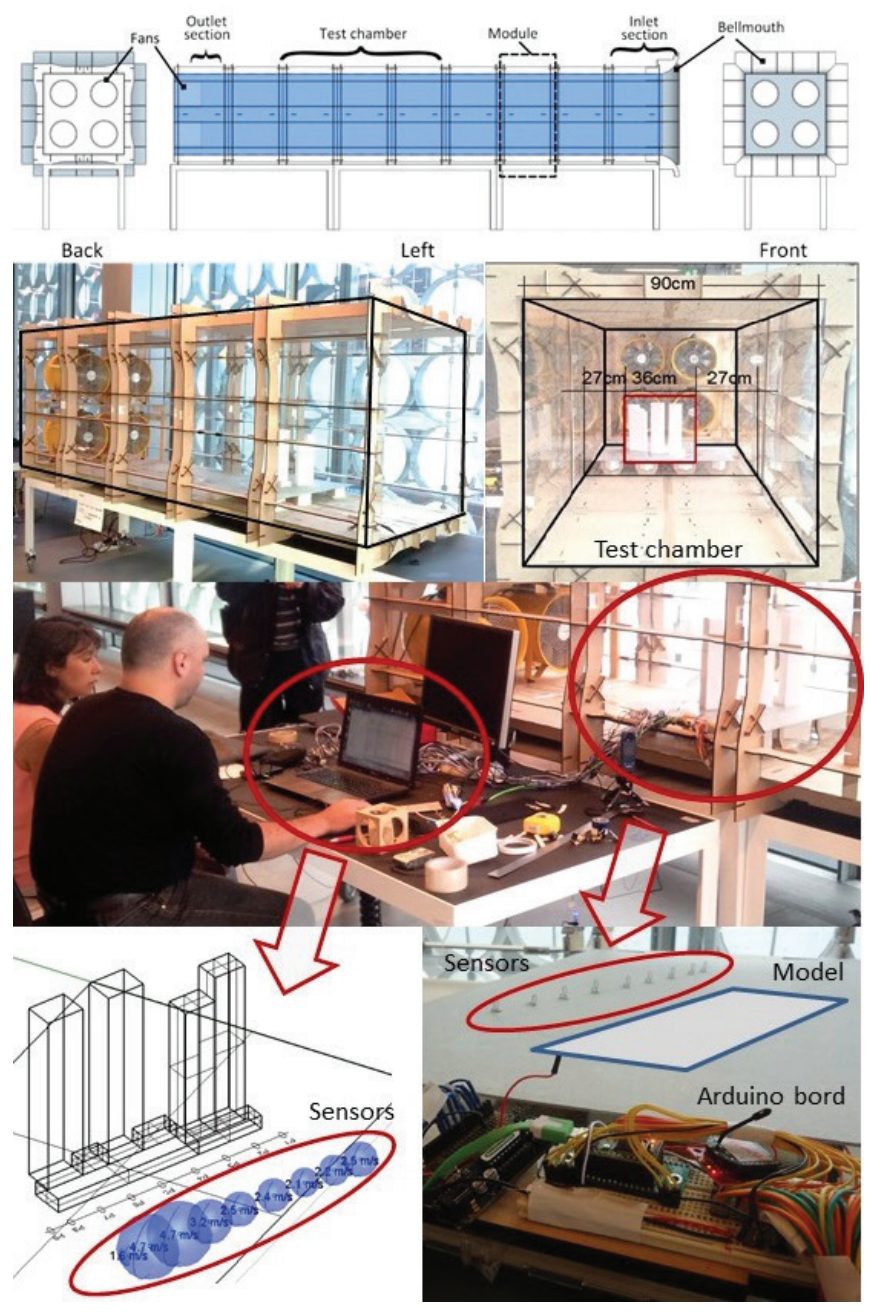

Figure 2: The mini airflow tunnel chamber, the connection of the sensors to Arduino board and the visualization on the computer. Author.

\section{Case study}

The case study chosen to assist the research is located in the city of Recife, northeast region of Brazil, where the climate is hot and humid and natural ventilation is considered the most important bioclimatic strategy to promote its citizens thermal comfort (Lamberts, Dutra e Pereira, 2004). Bittencourt and Cândido (2010) analyzed wind speed, frequency and direction based on data collected in the past 40 years in the weather station installed in Varzea neighborhood at 10 meters above the ground level. Sousa (2014) realized that the average wind frequency and velocity throughout the day should be most of the time satisfying for its citizens.

However, due to the development of the city without deep analysis and consideration of airflow pattern around buildings is easy to find urban areas of discomfort for wind speed (sometimes too high other times too low). In order to understand airflow process in Recife Sousa (2014) analyzed a central area of the city that is speculated to be redevelop with the construction of a building complex comprising a set of skyscrapers. The project, named Novo Recife, will include new housing, office spaces and hotels. The study goal was to understand the impact of the new building complex in the natural wind ventilation and provide guidelines to designers and urban planners, according to different patterns of urban settlement.

In the research, Sousa (2014) simulated the airflow in six scenarios of possible future development of the city. Nevertheless, for the purpose of this paper it was selected a part of the total area as case study since the focus during this investigation was not the area itself but the simulation tools used. In addition, part of the studied scenarios were excluded and the model was scaled to fit inside the mini airflow tunnel. Therefore, it was selected a part of three distinguished urban arrangements that varies on land use rates; distance between buildings and maximum height (see figure 3).

The first scenario was created based on the Novo Recife proposal. This model contains two buildings of 140 meters (46 floors), one of 130 meters (43 floors) and another of 110 meters (36 floors), in the building basement was also added an 11 meters high garage building (equivalent to 3 floors) connecting all skyscrapers. In the second scenario the distance between the buildings was increased in the ground level, the garage was reduced to the projection of the skyscrapers base and the area that was taken from the garage was transferred to the buildings, increasing its height. Therefore, the second model has two buildings of 152 metros (50 floors), one of 142 meters (47 floors) another of 122 meters (40 floors) and the garage buildings has 12 meters (4 floors). The third scenario has the double amount of buildings with approximately half the height of the second model. This means that this model has four buildings of 76 meters ( 25 floors) two buildings of 71 meters (23 floors) and another two buildings of 61 meters (20 floors).

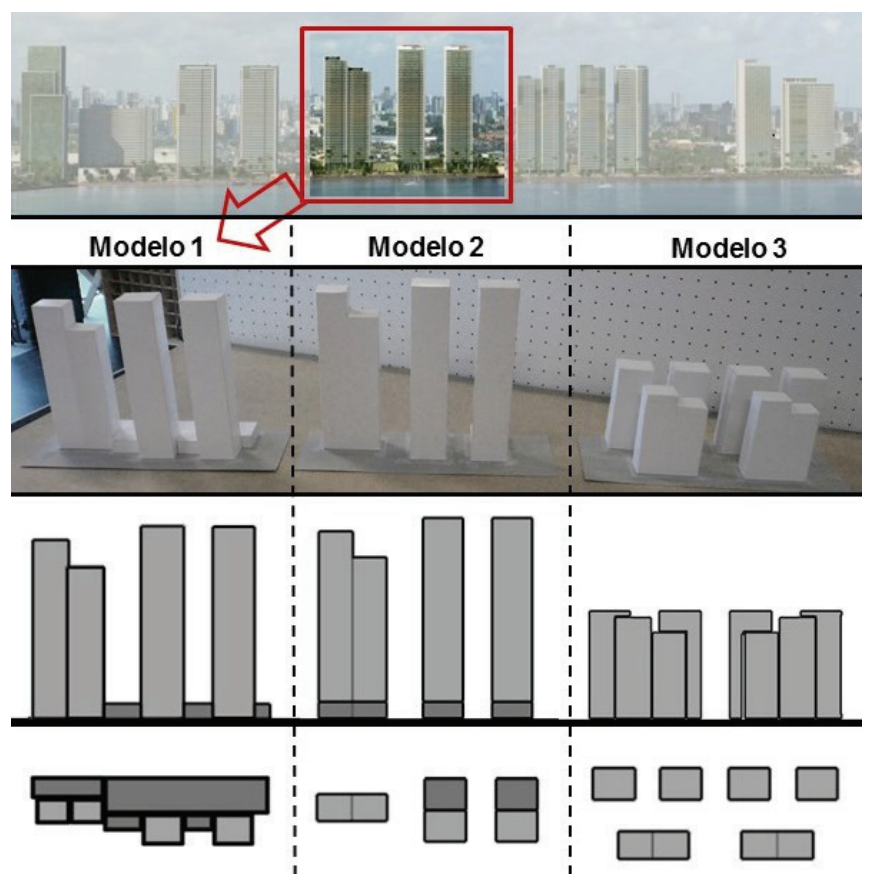

Figure 3: The three scenarios used in the testes. Author. 


\section{Experimentation set up}

With this investigation, it was possible to compare the use of three different tools of wind simulation according to three different steps: modeling, wind set up and visualization.

\section{Modelling step}

The models used in the CFD simulations were all drawn in AutoCAD 2D and manipulated on Sketchup for 3D volumetric definition. This was the most efficient way to create all models at the same time and it was possible because all software's have the option to import a vast variety of file formats making easier for professionals to analyze different design solutions developed using other programs. Additionally, Blender (the modular software that works with ODS-Studio) and Rhinoceros (the software necessary for the mini-airflow tunnel visualization) also offer options to import and develop tridimensional models. The mini airflow tunnel simulations required virtual scenarios and also physical models. The physical models were made of cardboard cut and assemble by hand at 1/500 scale of original to fit inside the wind tunnel and leave some area free of barrier around the model, providing enough space to the wind naturally circulate (see figure 2).

\section{Wind setup step}

Every tool has different levels of complexity to set up wind parameters. The manipulations of its definitions determine the quality of the results obtained in the simulations. In Flow Design user can control the domain size, wind direction, wind velocity and level of resolution. The graphic display is intuitive, easily understood by anyone without deep knowledge of airflow. On the other hand, ODS-Studio requires a period of training with tutorials, since it offers a wider range of options to control airflow configurations and different possibilities to refine the digital meshes for more detailed analysis.

For the simulation using Flow Design and ODS-studio, the wind speed inlet was define at $2,8 \mathrm{~m} / \mathrm{s}$ with orientation from southeast, the same configuration used by Sousa (2014), in the previous research. While, the wind speed inside the mini airflow tunnel was around $4 \mathrm{~m} / \mathrm{s}$, the only possible option, since the fans used in the study did not allow any power regulation.

Inside the mini airflow tunnel were installed nine wind sensors aligned in a row. This sensors were positioned at two different distances from the models: at $3 \mathrm{~cm}$ and $14 \mathrm{~cm}$ (representing 15 meters and 70 meters of distance) to evaluate the wind flow turbulence at leeward of the projected buildings. So for each scenario was necessary to run two simulations in order to have the 18 different points of analysis proposed in the methodology. The sensors went through a calibration process, which consisted in verifying if all sensors were providing the same wind speed data before placing any model inside the test chamber. Unfortunately, after calibration the number of sensors were reduced, as one of them was not collecting data properly. As a result, only sixteen points were considered in the following step (comparing the simulation tools).

\section{Visualization step}

All tools have different visualization systems, but apart from the mini airflow tunnel all of them represent wind velocity $(\mathrm{m} / \mathrm{s})$ in a graphic color scale. Flow Design gives an immediate feed-back so, users can change the configurations of wind set up while they are observing the air movement. In addition, the program offers four types of graphic representation of airflow (plans, lines, tubes and particles), similar to ODS-studio visualization options, but ODS-studio results are generated only after a few hours of processing an advanced numerical calculation. Therefore, ODS-studio simulation tool is more time consuming and more complex, and in this sense less attractive to the user. The data collected by the wind sensors inside the mini airflow tunnel was transmitted in real time to the computer where it was possible to visualized wind speed by bubbles that increase or decrease their size according to air velocity.

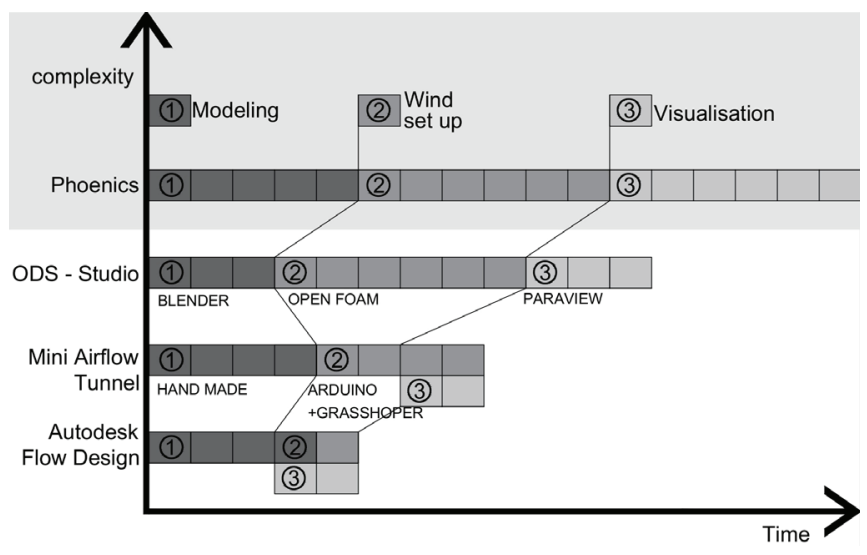

Figure 4: Graphic representation of time and complexity of each tool during the three different phases of simulation. Author.

Table 1: Summary of experience using the simulation tools. Author.

\begin{tabular}{|l|l|l|l|}
\hline $\begin{array}{l}\text { Tools for } \\
\text { operation }\end{array}$ & Learning & Feedback & Visualization \\
\hline $\begin{array}{l}\text { Autodesk } \\
\text { Flow Design } \\
\text { +Any 3D } \\
\text { modeler }\end{array}$ & Easy & Interactive & overall \\
\hline $\begin{array}{l}\text { ODS-Studio } \\
\text { + Blender + } \\
\text { Open Foam } \\
\text { +Praview }\end{array}$ & Difficult & Static & \\
\hline $\begin{array}{l}\text { Mini wind } \\
\text { tunnel + } \\
\text { Rhinoceros + } \\
\text { Grasshopper } \\
+ \text { Arduino + } \\
\text { Sensors }\end{array}$ & Regular & Interactive & details \\
\hline
\end{tabular}




\begin{tabular}{|l|l|l|l|}
\hline $\begin{array}{l}\text { CFD } \\
\text { Phoenics }+ \\
\text { Excel }\end{array}$ & Difficult & Static & $\begin{array}{l}\text { overall + } \\
\text { details }\end{array}$ \\
\hline
\end{tabular}

\section{Results}

Analyzing the outcome of the simulations the three scenarios exposed very distinct aerodynamic phenomena. The first scenario revealed a continuous area of low wind speed at leeward, due to the row effect produced by the garage building, and the acceleration of the wind speed on the streets aside of the buildings because of the corner effect and also because they were exposed to the main airflow.

In the second scenario the reduction of the garage building footprint provided greater spacing between the building at ground level this caused a reduction of the area of wake effect at leeward. On the other hand, the increase on buildings height intensified the corner effect and triggered the acceleration of wind speed (above $6 \mathrm{~m} / \mathrm{s}$ ) between the buildings, displaying that this is also not a good solution for this urban area. Finally, the third scenario with the decrease of building height and distance between buildings was the model that showed the highest turbulence wake and the most significant area of reduction in the air velocity at leeward of the buildings proving to be the worst solution for the ventilation in outdoor spaces affecting more houses from the surrounding area.

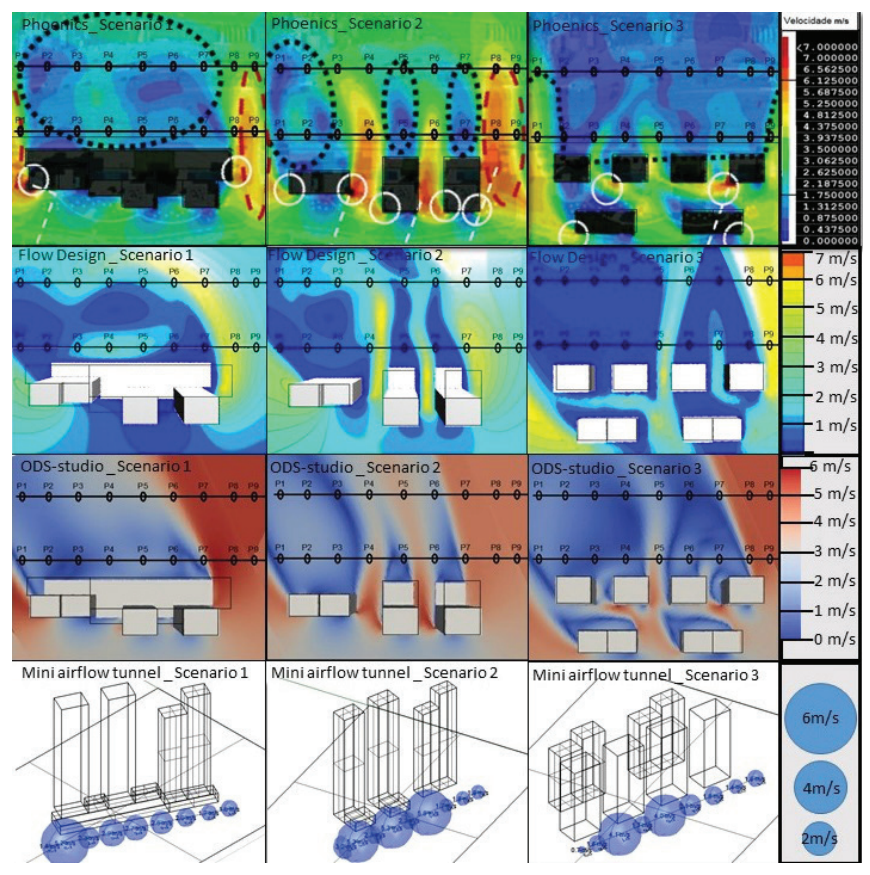

Figure 5: Representation of three scenarios simulated in Phoenics, Flow Design, ODS-Studio and mini wind tunnel. Author.

In figure 5, the maps of four analyses, it is possible to observe how the patterns of wind speed areas are similar in the vicinity of the buildings but with differences at the regions far behind the buildings. In the first column the leeward side is shown as a region of two islands of low wind velocity by Phoenics software, while the other simulations presents a single low wind speed region. In the same way, the third scenario simulated with Flow Design is less evident the deflection of the wind at the corners of the second line of buildings. This deflection is clearer in the simulations conducted with Phoenics and ODS-Studio. The reasons for these differences are probably related with several parameters from each tool used (flow domain dimensions, quality of the digital mesh, etc.). This makes evident that a simplified tool like Flow Design is limited to the observation of areas closed to buildings, while a more complete tool like Phoenics is efficient to visualise regions far from the buildings.
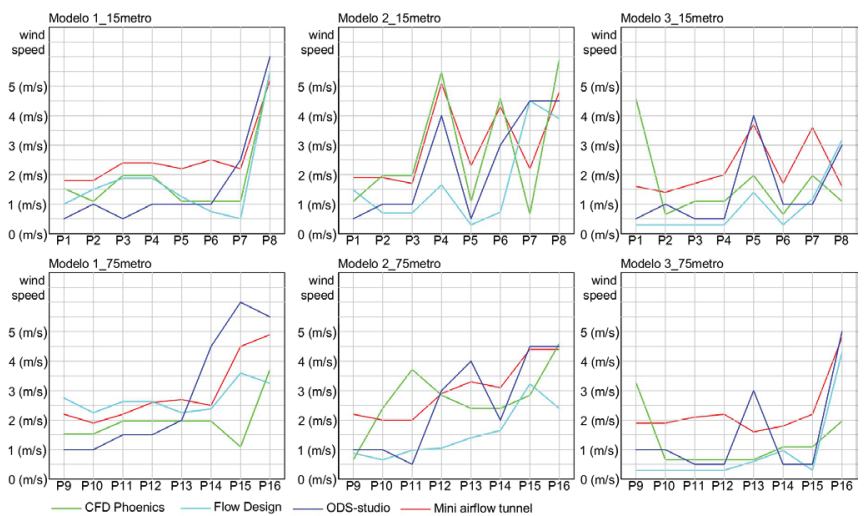

Figure 6: Graphic charts of wind speed in 16 different points. Author.

In figure 6 it is clear that the results between simulation techniques are more similar at regions closer to the buildings. The variation of wind intensity detected in each point by these tools shows patterns of higher wind velocities where the wind is 'funnelled' in-between the buildings. From the results presented it can be seen that these regions will have the greatest impact on pedestrian comfort. The magnitude of these accelerations of wind could be the evaluation criteria for the building designs.

Taken as reference the simulation results from Phoenics the mini airflow tunnel shows the best agreement with the relative patterns in wind speed results in close range to the buildings (from point one to eight, located at 15 meters of distance from the buildings). This cannot be said for the values measured further down-wind from the buildings (from point nine to sixteen, located at 70 meters of distance from the buildings). where effects from atmospheric boundary layer (ABL) conditions may be more evident, thus emphasising the importance to simulate urban wind conditions with $\mathrm{ABL}$ velocity profile conditions.

Moreover, this method of analysis was not efficient with Flow Design and ODS-Studio, because the plan view generated by the program is with perspective, making impossible to identify the exact same spot. This condition, is easily identified in figure 5 and 6, where the graphical chart 
demonstrates the wind speed data, making clear that this too softwares have a more resembling pattern of airflow because of this problem.

\section{Conclusion}

All tools revealed advantages and disadvantages in the interface systems they provide. Reinforcing the importance of studying this wind simulation tools for early design stages. Autodesk Flow Design had very limited options to set up wind parameters. For instance, the grid resolution is only defined by high or low standard and the user can not define the exact coordinates in the $(\mathrm{x}, \mathrm{y}, \mathrm{z})$ axes for better evaluation of the model. The ODS-Studio displayed more options to regulate airflow however; it has a steep learning curve than the other tools because it requires basic knowledge in three different computer applications. The mini wind tunnel has some limitations in reproducing the boundary layer effect as well some restrictions in relation to the size of the model. Finally, the results generated by all simulation tools were not as precise as the ones shown on CFD program Phoenics however the overall air flow performance was similar.

Considering the visualization system provided, two of the selected tools ran a rapid and interactive simulation of airflow (Flow design, and the mini airflow tunnel) and the other two (ODS-studio and Phoenics) generate a sequence of images of wind speed data after a few hour of processing. This means that Flow design and mini airflow tunnel show air movement and wind speed variations $(\mathrm{m} / \mathrm{s})$ that could be more interesting for educational enlightenment of fluid dynamic behavior than ODS-studio or Phoenics that demonstrate a final result of wind speed average. On the other hand, the two CFD tools (ODS-studio and Phoenics) show a more accurate final answer of the overall scenario and its details, while Flow Design lacks precision, the opposite of the mini airflow tunnel that provides the opportunity to visualize wind speed in the exact point were the sensor is located omitting the rest of the overall research site. In summary, all simulation tools demonstrate constraints so future work will seek to find others.

\section{Acknowledgments}

We thank to RMIT University for providing the space in SIAL (Spatial Information Architecture Laboratory) to develop this research.

\section{References}

Assis, E. (2006).Aplicações da climatologia urbana no planejamento da cidade: revisão dos estudos brasileiros. Revista de Urbanismo e Arquitetura, 7 (1). 20-25.

Aynsley, M. (1977). Architectural aerodynamics. Applied Science Publishers.

Autodesk (n.d.). Flow design. Retrieved from http://www. autodesk.com/products/flow-design/features/all/list-view
Bittencourt, L. Cândido, C. (2010) Ventilação natural em edificações. Procel Edifica.

Boris, J. (2005). Dust in the wind: Challenges for urban aerodynamics. Proceedings of 35th AIAA Fluid Dynamics Conference and Exhibit. AIAA Paper, 5953. 6-9.

Brandão, R. (2009). As interações Espaciais Urbanas e o Clima (Doctoral dissertation). Retrieved from http://www.teses.usp. br/teses/disponiveis/16/16132/tde-23032010-093854/pt-br. php

Cfd Online. (n.d.) Welcome to CFD Online, serving the CFD community since 1994. Retrieved from http://www.cfdonline.com/

Cham (n.d.) Phoenics Your Gateway to CFD Success. Retrieved from http://www.cham.co.uk/.

Costa, F. (2001). Ventilação e prescrições urbanísticas: Uma aplicação simulada no bairro de Petrópolis em Natal/ RN. (Master's thesis). Retrieved from http://repositorio.ufrn. br:8080/jspui/handle/123456789/12412.

Gandemer, J. (1978) Discomfort due to wind near buildings aerodynamic concepts. Washington, U.S. Govt. Print.

Kirkegaard, H., Hougaard, M., Staerdahl, W. (2008). On computational Fluid Dynamics Tools in Architectural Design, Aalborg University. Department of Civil Engineering Lamberts, R.; Dutra, L.; Pereira, F. (2004). Eficiência Energética na Arquitetura ( $2^{\mathrm{a}}$ ed.). São Paulo: Prolivros

Leite, R. (2010). Fortaleza Terra do vento: A influência da mudança nos padrões de ocupação do solo sobre a ventilação natural em cidade de clima tropical úmido (Master's thesis). Retrieved from http://www.teses.usp.br/teses/ disponiveis/16/16132/tde-10012011-111509/pt-br.php.

Marques, R. (2003). Ventilação e prescrições urbanísticas: uma aplicação simulada para a orla da praia do meio em Natal/ RN (Master's thesis). Retrieved from http://repositorio.ufrn. br:8080/jspui/handle/123456789/12297.

Melo, J.; Barbirato, G. (2011).Informações para o planejamento a partir da caracterização climática urbana: estudo em MaceióAl. Proceedings of. XI ENCAC VII ELACAC Encontro Nacional e Latino-Americano de Conforto no Ambiente Construído.

Moya, R. (2015). Empirical evaluation of three wind analysis tools for concept design of an urban wind shelter. Proceedings of Computer-Aided Architectural Design Research in Asia CAADRIA. 313 - 322.

Moya, R., Prohasky, D. (n.d.), Mini wind tunnel project. Retrieved from https://miniwindtunnel.wordpress.com/

Naboni, E. (2013). Environmental Simulation Tools in Architectural Practice. Proceedings of PLEA2013 - 29th Conference, Sustainable Architecture for a Renewable Future, ODS Engineering (n.d.). A framework for building simulation. Retrieved from http://www.ods-engineering.com/tools/odsstudio/

Oke. T. (1987). Boundary Layer climates. ( ${ }^{\mathrm{a}}$ ed.) Londres: Routledge.

Peregrino, P. (2005). Inter-relações existentes entre os escoamentos de ventos e os padrões de ocupação do solo nos bairros do Cabo Branco e Tambaú/ João Pessoa - PB. (Master's 
thesis). Retrieved from http://tede.biblioteca.ufpb.br:8080/ bitstream/tede/5540/1/arquivototal.pdf

Prata, A. (2005). Impacto da altura dos edifícios nas condições de ventilação natural do meio urbano. (Doctoral dissertation). Retrieved from www.teses.usp.br/teses/ disponiveis/16/16131/tde.../TESE_FINAL.pdf

Prohasky, D., Moya, R.; Watkins, S., Burry, J., Burry, M. (2014). Wind sensing with real-time visualisations for Designers An approach to understanding wind phenomena for pedestrian comfort using low cost wind sensors. Proceedings of Education and research in Computer Aided Architectural Design in Europe (ECAADE), 165 - 171.

Salim, F., Moya, R. (2012). Parallel Analysis of Urban
Aerodynamic Phenomena Using High and Low-Tech Tools. Proceedings of Education and research in Computer Aided Architectural Design in Europe (ECAADE), 621 - 629.

Sousa, J. (2014). Influência da forma urbana na ventilação natural: um estudo de caso no cais José Estelita, Recife. (Master's thesis). Retrieved from http://www.repositorio. ufpe.br/handle/123456789/13979.

Williams, M., Moya, R., Prohasky, D., Khorasgani, M., Watkins, S., Burry, M., Burry, J.; Belesky, P. (2015). A Physical and Numerical Simulation Strategy to Understand the Impact of the Dynamics in Air for the Design of Porous Screens. Proceedings of Conference: Symposium on Simulation for Architecture and Urban Design (SIMAUD); 1085 -1092. 